\title{
TINGKAT PERILAKU HIDUP BERSIH DAN SEHAT MASYARAKAT DI PESISIR PANTAI SASAK PASAMAN BARAT
}

\author{
Oleh: \\ Widya Prarikeslan dan Sri Mariya \\ Dosen Jurusan Geografi FIS Universitas Negeri Padang \\ Email: widya_geo@fis.unp.ac.id srimariya@yahoo.com
}

\begin{abstract}
Abstrak
Penelitian ini bertujuan untuk melihat perilaku masyarakat dalam rangka hidup bersih dan sehat di Pesisir Pantai Sasak Pasaman Barat. Tidak dapat dipungkiri bahwa permasalahan kebersihan lingkungan merupakan hal utama. Agama juga sangat menganjurkan kita untuk hidup bersih, dengan pesan Kebersihan adalah Sebagian dari Iman. Pesan tersebut menuntut kita bersih lahir dan batin. Perilaku hidup bersih dan sehat untuk menciptakan suatu kondisi bagi perorangan, keluarga, kelompok dan masyarakat untuk meningkatkan pengetahuan, sikap dan perilaku, melalui binaan dan pemberdayaan masyarakat. Penelitian ini merupakan penelitian survei dengan pendekatan explanatory research. Alat pengumpul data yang digunakan dalam penelitian ini adalah angket. Pelaksanaan kegiatan ini direncanakan untuk 1 tahap yakni dilakukan pada tahun 2016 yang memetakan dan menganalisis tingkatan PHBS. Dari hasil penelitian diperoleh PHBS di Nagari Sasak Pasaman Barat pada umumnya termasuk kategori Sehat II yang terdiri dari Jorong Pondok, Pasa Lamo, Padang Jaya Maligi, Pantai Indah Maligi dan Padang Indah Maligi. Sedangkan Sehat III terdapat pada jorong Suka Jadi Maligi dan Suka Indah Maligi. Dalam penelitian ini tidak ditemukan Tidak Sehat, Sehat I dan Sehat IV
\end{abstract}

\section{Kata Kunci : perilaku, masyarakat}

\section{PENDAHULUAN}

Kebersihan merupakan salah satu faktor penting yang mendorong kemajuan aktivitas dan kreatifitas individu untuk mencapai kesejahteraan yang berdampak pada semua lapisan masyarakat. Ada banyak hal yang bisa menjadi faktor penghubungnya. Umpamakanlah kebersihan itu kita sangkutkan dengan masalah kesehatan, maka akan timbul reaksi yang kuat antara keduanya. Jika kita hidup bersih maka pasti kita akan hidup sehat dan begitu juga sebaliknya. Jika kita tidak melakukan pola hidup bersih maka secara tidak langsung hal itu akan berpengaruh terhadap kesehatan kita.
Depkes RI 2009 menyatakan perilaku hidup bersih dan sehat di rumah tangga merupakan salah satu implementasi dalam mewujudkan hak asasi manusia yang patut dihargai dan diperjuangkan oleh semua pihak. Oleh karena itu menggerakkan dan memberdayakan keluarga untuk hidup sehat dan bersih menjadi tanggung jawab pemerintah kabupaten/kota beserta jajaran sektor terkait termasuk lembaga swadaya masyarakat, organisasi masyarakat, swasta dan dunia usaha untuk mewujudkan rumah tangga yang ber-PHBS.

Jadi berdasarkan landasan fakta tersebut di atas, maka dalam penelitian ini 
kami mencoba untuk menelusuri lebih spesifik tentang hal-hal yang mendasari terjadinya fenomena tersebut.

Tujuan khusus dari penelitian ini adalah diharapkan bisa mengetahui perilaku hidup bersih dan sehat masyarakat itu sendiri. Meliputi: mengetahui tingkatan perilaku hidup bersih dan sehat masyarakat yang tinggal di Nagari Sasak

\section{TINJAUAN PUSTAKA}

Perilaku hidup bersih dan sehat (PHBS)

Pengertian PHBS Perilaku Hidup

Bersih dan Sehat (PHBS) adalah sekumpulan perilaku yang dipraktikkan atas dasar kesadaran sebagai hasil pembelajaran, yang menjadikan seseorang, keluarga, kelompok atau masyarakat mampu menolong dirinya sendiri (mandiri) dalam kesehatan dan berperan aktif dalam mewujudkan kesehatan masyarakat. Dengan demikian, PHBS mencakup beratus-ratus bahkan mungkin beribu-ribu perilaku yang harus dipraktikkan dalam rangka mencapai derajat kesehatan masyarakat yang setinggi-tingginya. Dibidang pencegahan dan penanggulangan penyakit serta penyehatan lingkungan harus dipraktikkan perilaku mencuci tangan dengan sabun, pengelolaan air minum dan makanan yan memenuhi syarat, menggunakan air bersih, kan jamban sehat, pengelolaan limbah cair yang memenuhi syarat, memberantas jentik nyamuk, tidak merokok di dalam ruangan dan lain-lain. Di bidang kesehatan ibu dan anak serta keluarga berencana harus dipraktikkan perilaku meminta pertolonan persalinan oleh tenaga kesehatan, menimbang balita setiap bulan, mengimunisasi lengkap bayi, menjadi akseptor keluarga (MENKES, 2011).

Depkes RI 2009 rumah tangga berPHBS berarti mampu menjaga, meningkatkan dan melindungi kesehatan setiap anggota rumah tangga dari gangguan ancaman penyakit dan lingkungan yang kurang kondusif untuk hidup sehat.

Meningkatnya perilaku hidup bersih dan sehat di tatanan rumah tangga, tatanan institusi pendidikan, tatanan tempat kerja, tatanan tempat umum dan tatanan fasilitas kesehatan. Tujuan terpenting dari PHBS ini adalah:

1. Meningkatkan komitmen dan aliansi strategis pemangku kepentingan ditingkat pusat, provinsi, kabupaten, kota, kecamatan, desa dan kelurahan untuk pembinaan perilaku hidup bersih dan sehat (PHBS).

2. Meningkatkan aliansi dan kemitraan dengan swasta/ dunia usaha

3. Meningkatkan peran serta organisasi masyarakat/kelompok potensial

4. Menembankan kebijakan pembinaan PHBS ditatanan rumah tana, instusi pendidikan, tempat kerja, tempat umum dan fasilitas kesehatan di semua tingkat administrasi pemerintahan.

5. Memperkuat gerakan dan peran serta masyarakat melalui PHBS di tatanan rumah tangga, institusi pendidikan, tempat kerja, tempat umum dan fasilitas kesehatan.

6. Meningkatkan akses informasi dan edukasi kepada masyarakat di tatanan rumah tangga, institusi pendidikan, tempat kerja, tempat umum dan fasilitas kesehatan.

7. Meningkatkan kapasitas pengelola pembinaan PHBS di tatanan rumah tangga, institusi pendidikan, tempat kerja, tempat umum dan fasilitas kesehatan.

$$
\text { Peningkatan PHBS tersebut }
$$
dilaksanakan melalui 5 tatanan, diantaranya adalah tatanan rumah tangga. Terdapat 10 indikator PHBS tatanan rumah tangga, yaitu; 
a. Pertolongan persalinan oleh tenaga kesehatan,

b. Bayi diberi ASI ekslusif,

c. Mempunyai jaminan pemeliharaan kesehatan,

d. Ketersediaan air bersih,

e. Ketersediaan jamban sehat,

f. Kesesuaian luas lantai dengan jumlah penghuni,

g. Lantai rumah bukan lantai tanah,

h. Tidak merokok di dalam rumah,

i. Melakukan aktivitas fisik setiap hari

j. Makan buah dan sayur setiap hari.

Keberhasilan program PHBS tatanan rumah tangga, didasarkan kepada 10 indikator yang dibagi menjadi 4 tingkatan atau kategori: Sehat I, Sehat II, Sehat III, dan Sehat IV; dengan target pemerintah yaitu tercapainya penduduk Indonesia yang ber-PHBS pada tingkat Sehat IV (Depkes RI, 2006).

\section{Struktur Sosial}

Struktur Sosial terbentuk dari hubungan antara individu dalam bentuk status dan peranan masing-masing, individu dan kelompok kelompok yang memunculkan status sosisl dan pola interaksi dan hubungan individu dengan lingkungan yang menimbulkan kebudayaan material dan nonmaterial. Pola hubungan yang terjadi akan menyebabkan ciri masyarakat tersebut berbeda dengan masyarakat lainnya.

Koentjaraningrat menjelaskan bahwa struktur sosial adalah kerangka yang dapat menggambarkan kaitan berbagai unsur dalam masyarakat. Sementara itu Soeleman B Taneko menjelaskan bahwa struktur sosial adalah keseluruhan jalinan antara unsur-unsur soaial yang pokok, yakni kaidah-kaidah sosial, lembaga-lembaga sosial, kelompok- kelompok sosial, serta lapisan-lapisan sosial.

Struktur sosial, terkait dengan status dan peranan. Status atau kedudukan diartikan sebagai tempat atau posisi seseorang dalam kelompok sosial. Adapun kedudukan sosial tempat seseorang secara umum dalam masyarakat berkaitan dengan orang lain berkaitan dengan lingkungannya, harga diri dan hak-hak serta kewajiban. Dengan demikian tanpa adanya orang lain tidak aka nada status sosial, sebab status sosial terjadi akibat struktur sosial yang secara normatif menempatkan seseorang di dalam posisi sosial berdasarkan kualifikasi pribadinya dengan orang-orang di sekitarnya.

Berdasarkan

proses

memperolehnya, kedudukan sosial dibedakan menjadi dua:

1. Kedudukan seseorang yang diperoleh dari bawaannya (ascribed status) yang diantaranya kedudukan yang bersifat biologis seperti gender, dan kedudukan yang bersifat historis seperti keturunan pejabat tinggi, keturunan raja dan sebagainya.

2. Kedudukan yang diperoleh dari usaha atau dengan disengaja (achieved status) seperti seseorang yang karena kegigihannya berhasil meraih gelar sarjana, dari gelar tersebut menyebabkan dia bekerja diperusahaan besar dengan gaji yang besar.

(Elly, M.Setiadi, USman Kolip. 2011)

Status Sosial dikelompokkan menjadi dua (James. M. Henslin. 2006: 9394) :

1. Status Bawaan (ascribed Status), bersifat tidak sukarela, tidak meminta dan tidak dapat memilihnya. Mewarisi beberapa status bawan pada waktu lahir, 
seperti ras atau etnis, jenis kelamin dan kelas sosial orang tua.

2. Status Capaian (achieved status) sebaliknya, bersifat sukarela. Status yang diraihatau dicapai sebagai hasil dari upaya menjadi mahasiswa (pendidikan), seorang teman, seorang pasangan hidup, pendeta, imam, dan laian-lain .

\section{Achieved Status}

Achieved status merupakan status yang diperoleh sesorang dengan usahausaha yang disengaja. Status ini tidak diperoleh atas dasar keturunan, akan tetapi bergantung pada kemampuan individu dalam mencapai tujuannya. Jadi status ini bersifat terbuka bagi siapa saja. Contoh setiap orang biasa jadi hakim asalkan memenuhi persyaratan tertentu, seperti lulusan fakultas hukum, memiliki pengalaman kerja dalam bidang hukum, dan lulus ujian sebagai hakim. Dari pengertian diatas maka untuk achieved status juga dapat kita lihat dari tingkat pendidikan, pendapatan dan pekerjaan.

Pendapatan merupakan semua penerimaan uang, baik dari pekerjaan, bunga atas tabungan, dividen, laba atau transver dari pemerintah. Serta masuk kedalamnya manfaat medis, dll ( Case.K, 2006).

\section{METODE PENELITIAN Lokasi Penelitian}

Secara geografis Nagari Sasak Kecamatan Sasak Ranah Pasisie Kabupaten Pasaman Barat terletak antar $00^{\circ} 14^{\prime} 15^{\prime}$ ' LU sampai 00 03'30' 'LU dan 99 $35^{\prime} 00^{\prime \prime}$ 'BT sampai $99^{\circ} 42^{\prime} 20^{\prime \prime}$ 'BT dengan ketinggian 0-10 $\mathrm{m}$ dari permukaan laut. Secara administrasi pemerintah Nagari Sasak berbatasan langsung dengan nagari:

Sebelah Utara : Nagari Sunagi Aua

Sebelah Selatan : $\quad$ Samudera Indonesia
Sebelah Barat : Nagari Sungai Aua

Sebelah Timur : Nagari Lingkung Aua

Jumlah penduduk Nagari Sasak adalah 13860 orang yang tersebar pada 11jorong seperti terlihat pada tabel 1:

Tabel 1 Jumlah Penduduk dan KK di Nagari Sasak

\begin{tabular}{|l|l|l|l|}
\hline No & Nagari/Jorong & $\begin{array}{l}\text { Jumlah } \\
\text { Penduduk } \\
\text { (Jiwa) }\end{array}$ & $\begin{array}{l}\text { Jumlah } \\
\text { KK }\end{array}$ \\
\hline 1 & Sialang & 796 & 194 \\
\hline 2 & Pisang Hutan & 1475 & 464 \\
\hline 3 & $\begin{array}{l}\text { Rantau } \\
\text { Panjang }\end{array}$ & 1240 & 375 \\
\hline 4 & $\begin{array}{l}\text { Padang } \\
\text { Halaban }\end{array}$ & 2104 & 520 \\
\hline 5 & Bandar Baru & 828 & 203 \\
\hline 6 & Pasar Lamo & 633 & 415 \\
\hline 7 & Pondok & 2369 & 667 \\
\hline 8 & $\begin{array}{l}\text { Pantai Indah } \\
\text { Maligi }\end{array}$ & 1242 & 431 \\
\hline 9 & $\begin{array}{l}\text { Suka Damai } \\
\text { Maligi }\end{array}$ & 696 & 283 \\
\hline 10 & $\begin{array}{l}\text { Suka Jadi } \\
\text { Maligi }\end{array}$ & 910 & 320 \\
\hline 11 & $\begin{array}{l}\text { Padang Jaya } \\
\text { Maligi }\end{array}$ & 1560 & 519 \\
\hline
\end{tabular}

Sumber Profil Nagari Sasak 2016

Nagari Sasak dilalui oleh 2 sungai yaitu Batang Pasaman dan Batang Kapa yang bersatu disatu muara yaitu muara Sasak, Batang Pasaman merupaka sungai yang terbesar didaerah Kabupaten Pasaman Barat (Profil Nagari Sasak 2016). Ditinjau dari pekerjaan ada beberapa jenis pekerjaan diantaranya: 
Tabel 2. Sebaran jenis pekerjaan yang mayoritas di Nagari Sasak

\begin{tabular}{|l|l|c|c|c|c|}
\hline No & Nagari/Jorong & $\begin{array}{l}\text { Nelayan } \\
\text { (orang) }\end{array}$ & $\begin{array}{l}\text { Dagang } \\
\text { (orang) }\end{array}$ & $\begin{array}{l}\text { Swasta } \\
\text { (orang) }\end{array}$ & $\begin{array}{l}\text { Tani } \\
\text { (orang) }\end{array}$ \\
\hline 1 & Sialang & 1 & 32 & 8 & 600 \\
\hline 2 & Pisang Hutan & 15 & 30 & 50 & 350 \\
\hline 3 & Rantau Panjang & 4 & 300 & 29 & 6 \\
\hline 4 & Padang Halaban & 305 & 25 & 9 & 350 \\
\hline 5 & Bandar Baru & 67 & 10 & 3 & 115 \\
\hline 6 & Pasar Lamo & 300 & 25 & 20 & 16 \\
\hline 7 & Pondok & 750 & 53 & 7 & 15 \\
\hline 8 & Pantai Indah Maligi & 521 & 14 & 23 & 5 \\
\hline 9 & Suka Damai Maligi & 364 & 17 & 21 & 6 \\
\hline 10 & Suka Jadi Maligi & 624 & 22 & 19 & 4 \\
\hline 11 & Padang Jaya Maligi & 451 & 10 & 25 & 7 \\
\hline
\end{tabular}

Sumber Profil Nagari Sasak 2016

\section{Populasi dan Sampel Penelitian}

Subjek penelitian adalah masyarakat yang tinggal di dekat atau di jorong pantai Nagari Sasak, yang berjumlah 242 KK yang terdiri dari jorong Pasa Lamo,
Pondok, Pantai Indah Maligi, Suka Damai Maligi, Suka Jadi Maligi dan Padang Jaya Maligi yang diambil dari 9\% jumlah KK masing-masing jorong dapat dilihat pada tabel 3:

Tabel 3. Populasi dan sampel penelitian

\begin{tabular}{|c|l|l|l|}
\hline No & Nagari/Jorong & $\begin{array}{l}\text { Jumlah } \\
\text { KK }\end{array}$ & $\begin{array}{l}\text { Jumlah } \\
\text { sampel }\end{array}$ \\
\hline 1 & Pasar Lamo & 415 & 38 \\
\hline 2 & Pondok & 667 & 60 \\
\hline 3 & Pantai Indah Maligi & 431 & 40 \\
\hline 4 & Suka Damai Maligi & 283 & 21 \\
\hline 5 & Suka Jadi Maligi & 320 & 30 \\
\hline 6 & Padang Jaya Maligi & 519 & 48 \\
\hline & Jumlah & & 242 \\
\hline
\end{tabular}

Sumber Profil Nagari Sasak 2016

\section{Teknik Pengumpulan Data}

Metode yang digunakan untuk mendeskripsikan data meliputi pengumpulan, pengorganisasian, serta menyajikan data. Penyajian data dapat dijelaskan dalam bentuk grafik.

\section{HASIL DAN PEMBAHASAN}

\section{Perilaku Hidup Bersih dan Sehat}

Mencapai visi Indonesia sehat Departemen Kesehatan telah melakukan upaya pemberdayaan masyarakat dengan melakukan sosialisasi mengenai pentingnya PHBS di rumah tangga. Berdasarkan akumulasi skor pada indikator PHBS maka dapat dilihat seperti pada Gambar 1. di bawah ini 


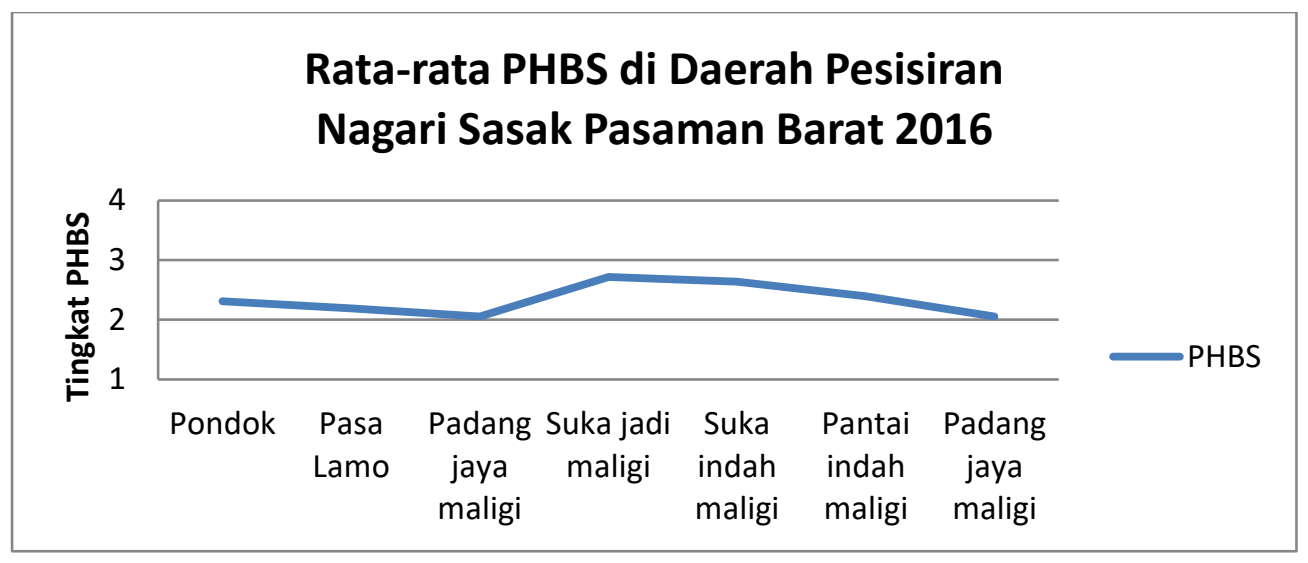

Gambar 2. Grafik rata-rata PHBS di pesisir pantai Sasak

Berdasarkan Gambar 2 diatas, diketahui bahwa PHBS di Nagari Sasak Pasaman Barat pada umumnya termasuk kategori Sehat II yang terdiri dari Jorong Pondok, Pasa Lamo, Padang Jaya Maligi, Pantai Indah Maligi dan Padang Indah
Maligi. Sedangkan Sehat III terdapat pada jorong Suka Jadi Maligi dan Suka Indah Maligi. Dalam penelitian ini tidak ditemukan Tidak Sehat, Sehat I dan Sehat IV

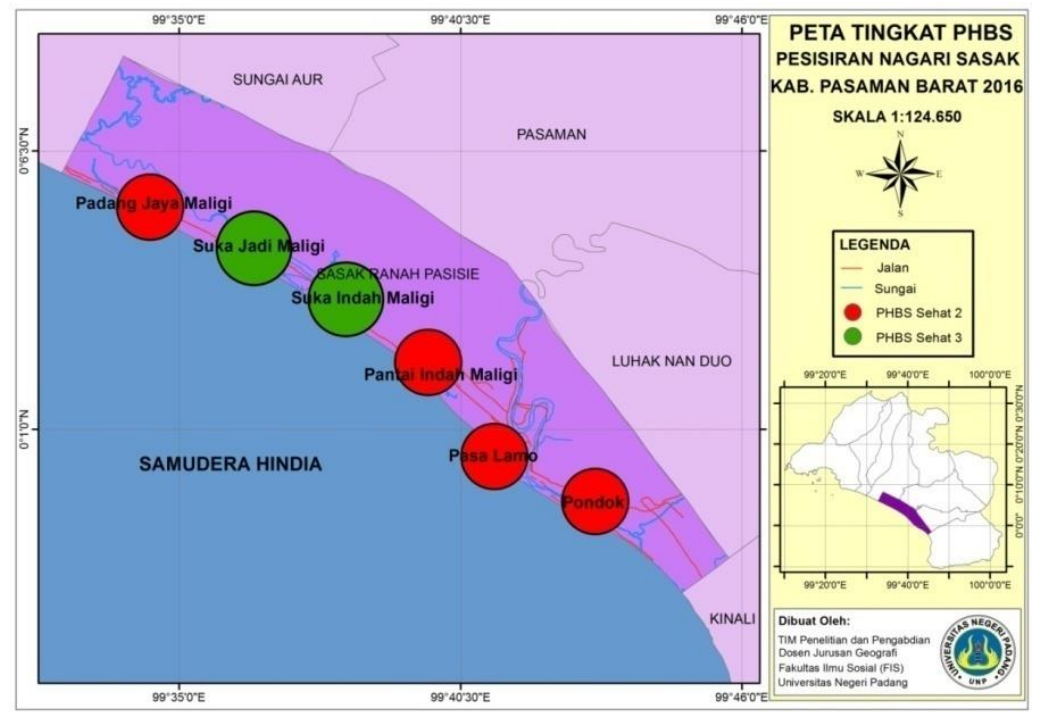

Perilaku Hidup Bersih dan Sehat (PHBS) berdasarkan tingkat pendidikan Kepala Keluarga (KK) yang tinggal di Nagari Sasak berpendidikan SD sekolah sebanyak 50\%, SMP sebanyak 26\%, SMA sebanyak $22 \%$ dan yang tidak sekolah sebanyak $1 \%$. Menunjukan bahwa hubungan yang sangat signifikan antara pendidikan dengan perilaku hidup bersih dan sehat.
Pekerjaan di Nagari Sasak ini mayoritas masyarakat adalah nelayan sebanyak 85\%, swasta $14 \%$ dan PNS sebanyak $1 \%$, aktivitas nelayan ini sangat bergantung terhadap cuaca. Jika musim hujan banyak hari-hari mereka yang dihabiskan dirumah atau ke warung, sehingga pendapatannya pun terganggu atau berkurang. Para istri kebanyakan bekerja sebagai ibu rumah tangga, dimana 
mereka hanya mengandalkan penghasilan dari tangkapan ikan.

Penelitian ini menunjukan bahwa masyarakat yang berada di Nagari Sasak berada pada Sehat II dan Sehat III, artinya dari 10 indikator PHBS menunjukan bahwa secara keseluruhan indikator tersebut tidak dilakukan oleh masyarakat. Dari 6 Jorong yang diteliti 4 jorong berkategori Sehat II dan hanya 2 jorong yang berkategori Sehat III. Ini memperlihatkan karakteristik masyarakat yang bekerja sebagai nelayan trodisional yang kebanyakan berpendidikan SD diasumsikan rendahnya pemahaman mereka terntang PHBS.

Menurut Kusnadi (2003) masyarakat dipesisir pantai secara umum merupakan masyarakat tradisional yang berpenghasilan pas-pasan. Tergolong miskin yang disebabkan oleh faktor alamiah, yaitu semata-mata bergantung pada hasil tangkapan ikan yang musiman. Sedangkan nonalamiah keterbatasan teknologi alat tangkap ikan. Sehingga berpengaruh dengan pendapatan keluarga.

Sebanyak 33\% dibawah UMR pendapatan berdampak pada ketersediaan pangan, tingkat pendidikan dalam keluarga nelayan. Rumah masyarakat yang tinggal di dekat pantai Sasak termasuk tidak layak huni, karena pada umumnya rumah tidak memiliki MCK dan semi prmanen yang terdiri dari 1 kamar tidur dan 1 ruangan keluarga dengan anggota keluarga yang lebih dari 2 orang. Dengan keterbatasan ekonomi akan menjadikan PHBS bukan dianggap suatu kebutuhan.
Jadi dari hasil yang diperoleh di lapangan banyak hal yang masih luput dari perhatian masyarakat diantaranya bayi tidak mendapatka ASI eksklusif dan pemberian makanan pendamping ASI pada bayi yang berusia dibawah 6 bulan, sulitnya air bersih dimana masyarakat memanfaatkan sumur buatan 1 untuk bersama, tidak ada jamban sehat karena pada umumnya masyarakat yang tinggal dekat pantai mengandalkan laut tempat jamban mereka, setiap rumah tidak mempunyai jamban. Tidak ada pemberantasn jentik, malah air dibiarkan tergenang dan membusuk di pekarangan rumahnya. Di daerah ini juga tidak ada tempat pembuangan limbah dan sampah rumah tangga, sehingga limbah dan sampah dibuang ke pasir di lingkuangan tempat tinggal, yang mana meninggalkan bau tidak sedap. Pada saat hujan turun semua sampah yang ada terbawa ke laut, sehingga laut atau perairan pantai penuh dengan sampah yang akan menjadikan laut tercemar. Pencemaran laut dan perairan pantai ini sangat mempengaruhi keberadaan ikan. Ikan akan mencari lokasi yang tidak terjadi pencemaran, sehingga nelayan tradisional yang hanya mampu beroperasi di perairan pantai karena keterbatasan ekonimi sangat susah untuk mendapatkan ikan. Menurut Kusnadi (2004). Nelayan tradisional kegiatan penangkapan ikan dilakukan dalam sehari satu kali melaut. Secara nasional, mereka memberikan kontribusi yang signifikan terhadap produktifitas perikanan tangkap. 


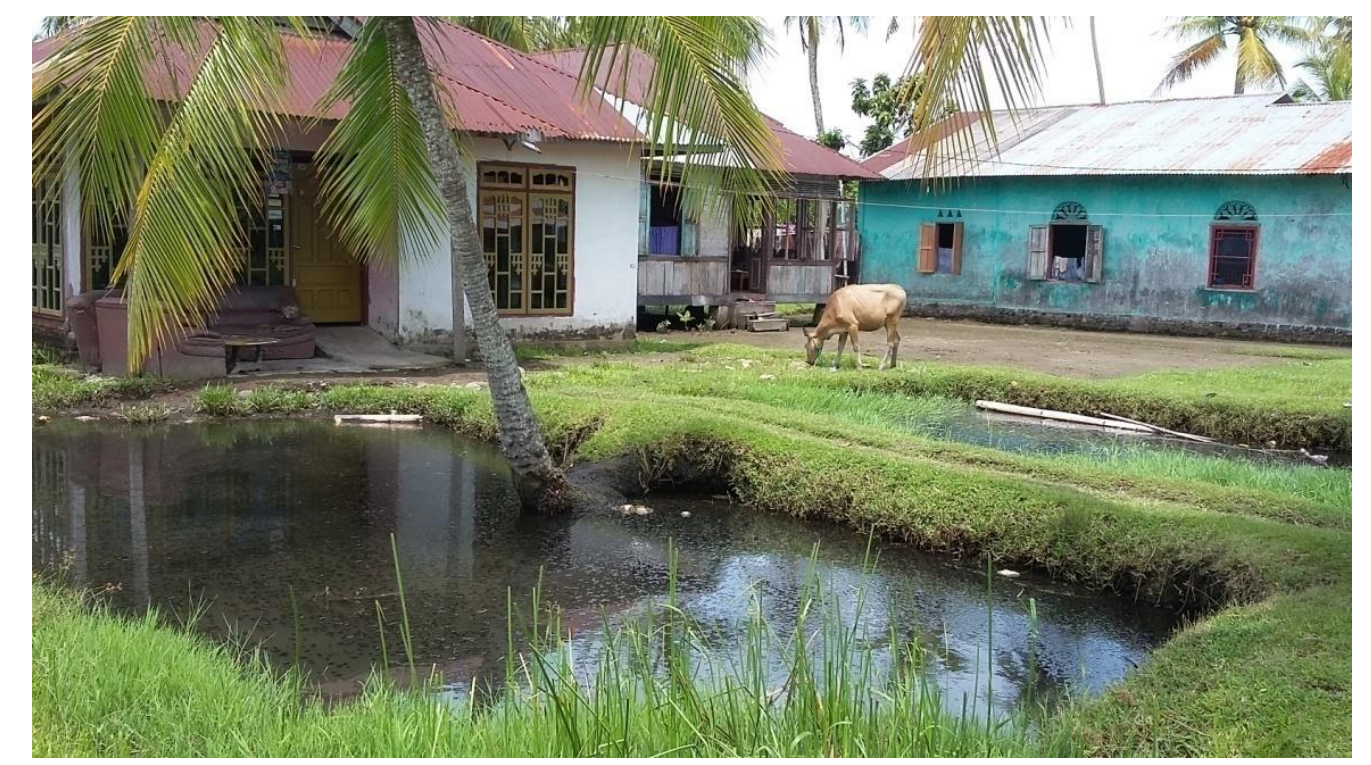

Gambar 2. Air tergenang dan membusuk

Gambar 2 juga terlihat hewan ternak dan kotorannya bertebaran di dekat tempat tingga masyarakat. Rumah dan kandang ternak yang sangat berdekatan yang berjarak kurang dari $1 \mathrm{~m}$ dari rumah warga, dimana setiap hari menghirup udara busuk yang berasal dari kotoran hewan ternak. Tidak tersedianya tempat khusus pembuangan kotoran ternak, masyarakat hanya membiarkan saja kotoran tersebut berada di lingkungannya dan hilang nanti jika tersapu oleh air hujan. Sampah yang dihasilkan oleh masyarakat yang tinggal disini langsung dibuang ke laut, sehingga laut menjadi tercemar. Indikator PHBS yang lain yaitu aktivitas kepala keluarga di Nagari Sasak ini pada umumnya nelayan. Aktivitas ini tidak dilakukan setiap hari tergantung musim dan cuaca, kalau cuaca buruk nelayan tidak akan melaut dan juga tidak ada kerja sampingan untuk menambah penghasilan. Nelayan hanya mencari nafkah jika cuaca sudah kembali baik. Selama tidak melaut nelayan mencukupi kebutuhan dengan meminjam kepihak lain dan membayarnya pada saat mulai melaut lagi, sehingga kehidupan mereka ' kali lobang tutup lobang'.

Rata-rata kepala keluarga yang tinggal di Nagari Sasak ini mengkonsumsi rokok, dalam merokok mereka tidak memperhatikan lingkungan sekitar, tidak mempedulikan kesehatan anak-anak dan bayi. Perilaku merokok disembarangan itu akan membahayakan orang lain bahkan dirinya sendiri.

Menkes (2004) Keberhasilan kesehatan dalam mencapai sasaran stratis tahun 2014 dan taret-taret Millennium Development Goals tahun 2015 sangat ditentukan oleh keberhasilan dalam menciptakan dan melestarikan perilaku hidup masyarakat yang berorientasi kepada kebersihan dan kesehatan. Oleh sebab itu upaya pembinaan Perilaku Hidup Bersih dan Sehat (PHBS) merupakan upaya sangat strategis yang harus menjadi perhatian para pelaku kepentingan (stakeholders). Dalam Rencana Strategi Kementerian Kesehatan, dijadikan tolok ukur keberhasilan pembinaan PHBS adalah persentase rumah tangga yang sudah mempraktekan PHBS. Namun 
disadari bahwa PHBS di rumah tangga memiliki hubungan saling mempengaruhi dengan PHBS di tatanan-tatanan lain, yaitu pendidikan,tempat kerja, tempat umum dan fasilitas kesehatan.

Kapasitas pengelolaan tatanan dapat ditingkatkan, sehingga pembinaan PHBS tidak sekedar merupakan tugas dan tanggun jawab pemerintah, melainkan juga seluruh komponen masyarakat. peraturan di desa atau kelurahan yang melandasi pembinaan PHBS di rumah tangga. Adanya peran aktif pemuka masyarakat dan organisasi kemasyarakatan dalam pembinaan PHBS di rumah tangga.

\section{SIMPULAN}

Pendidikan kepala keluarga yang tinggal di pesisir pantai Sasak adalah SD sebanyak 50\%. Pekerjaan Masyarakat pada umumnya yaitu sekitar $85 \%$. Terdapat pengaruh antara pekerjaan, pendidikan dan pedapatan terhadap PHBS. Semakin tinggi pendidikan, pekerjaan dan pendapatan maka perilaku hidup bersih dan sehat juga semakin meningkat dan semakin rendah pendidikan, pekerjaan dan pendapatan maka perilaku hidup bersih dan sehat juga semakin menurun. PHBS masyarakat di Nagari Sasak tergolong ke Sehat II dan Sehat III

\section{DAFTAR PUSTAKA}

Case.K, 2006. Prinsip-prinsi Ekonomi, Erlangga, Jakarta,

Damar, A, 2003.' 'Effects of Enrichment on Nutrient Dynamics Phytoplankton Dynamics and Productivity Indonesia Tropical Waters : A Comparation between Jakarta Bay, Lampung Bay and Semangka Bay ',, PHD Thesis, The Faculty of Mathematics and Nat, Sci, Christian Albrechts- Univ, Keil,.

Depkes RI, 2009. Pembinaan dan Penilaian Perilaku hidup bersih dan sehat Rumah Tangga Melalui TIM penggerak PKK, Jakarta,.

Effendi. H, 2000''Telaahan Kuliah Air: Bagi Pengelolaan Sumberdaya dan Lingkungan Perairan', Fakultas Perikanan dan Ilmu Kelautan, IPB,

Elly, M.Setiadi, USman Kolip. 2011. Pengantar Sosiologi (Pemahaman Fakta dan Gejala Permasalahan Sosial: Teori Aplikasi dan Pemecahannya).Jakarta: Kencana Prenada Media Group.

Effendi ferry , 2009.Keperawatan kesehatan komunitas, , penerbit salemba medika James. M. Henslin. 2006. Sosiologi dengan Pendekatan Membumi. Jakarta:Erlangga.

Kusnadi, 2004. Polemik Kemiskinan Nelayan, Pustaka Yogyakarta Mandiri, Yogyakarta.

LAPI ITB. 2001. (Lembaga Afiliasi Penelitian dan Industri ITB), Pengembangan Basis Data Pencemaran Laut dan Perencanaan Pengendalian Pencemaran Laut, ITB, Bandung

MENKES, 2011. Pedoman Pembinaan PHBS, Peraturan Mentri Kesehatan Republik Indonesia NOMOR: 2269/MENKES/PER/XI/

P2O LIPI, 1998. Proyek Inventarisasi dan Evaluasi Potensi Laut - Pesisir, Laporan Tahunan, LIPI, Jakarta, 